\title{
First total synthesis of a guanidine alkaloid Nitensidine D using immobilized ionic liquid, microwaves and formamidinesulfinic acid
}

\author{
SHALLU, M L SHARMA and JASVINDER SINGH* \\ Department of Chemistry and Centre of Advanced Studies in Chemistry, Panjab University, \\ Chandigarh 160 014, India \\ e-mail: jsbrar_pu@yahoo.com
}

MS received 7 March 2014; accepted 16 October 2014

\begin{abstract}
An efficient first total synthesis of a naturally occurring guanidine alkaloid, Nitensidine D isolated from ethanol extract of Pterogyne nitens has been described. Geraniol has been used as the starting material. $\mathrm{N}$-alkylation of phthalimide has been achieved using immobilized ionic liquid and formamidinesulfinic acid acts as the guanylating reagent.
\end{abstract}

Keywords. Guanidine alkaloid; microwaves; immobilized ionic liquid; formamidinesulfinic acid.

\section{Introduction}

The discovery of biologically active molecules is crucial for both the development of new therapeutics ${ }^{1}$ and to provide tools for the elucidation of cellular processes. $^{2}$ Natural extracts, collections and combinatorial libraries of synthetic compounds are screened for searching these compounds. Natural products play an important role, particularly in the anti-cancer and antiinfective areas as greater than $60 \%$ of the drugs that are now available were estimated to be derived from them. ${ }^{3}$

Many natural products containing guanidine have been isolated and have attracted a lot of attention owing to their wide range of biological activities, ${ }^{4}$ basically arising from the two parallel interactions of the guanidinium ion with phosphate and carboxylate-containing biomolecules. ${ }^{5}$ In addition, due to the strong binding ability of guanidine with anionic compounds, guanidine containing molecules have applications as chemical tools. Synthetic guanidine compounds have also been utilized as host receptor molecules for phosphate and carboxylate containing guest molecules. ${ }^{6}$

A number of unusual guanidine alkaloids displaying a broad spectrum of biological activities have been isolated from marine organisms ${ }^{7}$ whereas, in the plant kingdom, these are restricted to the families of Euphorbiaceae and Leguminosae. ${ }^{8}$ Pterogyne nitens Tul. (Fabaceae, Caesalpinioideae) popularly known as 'bálsamo,' 'yvira-ró,' 'cocal' and 'amendoinzeiro' is a native tree common in South America. Previous

*For correspondence phytochemical studies with the leaves and fruits of $P$. nitens have demonstrated the presence of two terpenoid guanidine alkaloids (pterogynine, ${ }^{9}$ pterogynidine ${ }^{8 \mathrm{a}}$ ), three guanidine alkaloids (Nitensidine A, B, C) which exhibited cytotoxic activity towards the DNA-repairdeficient yeast mutant RS 321 and moderate cytotoxic activity against $\mathrm{CHO}$ Aux B1 cells ${ }^{10}$ and phenolic compounds with myeloperoxidase inhibitory and radical scavenging activities. ${ }^{11}$ Further investigations of the ethanolic extracts of $P$. nitens due to its cytotoxic activity in the MTT assay resulted in the isolation of two new guanidine alkaloids Nitensidine D and E. ${ }^{12}$

Ionic liquids (ILs) have become increasingly used solvents and catalysts in 'green' chemistry due to their unique properties. ${ }^{13}$ The most important technical problems in the industrial IL applications using soluble IL catalysts, are their recovery and subsequent reuse or disposal. Immobilization of the catalyst on a solid support provides the advantage of easy isolation at the end of the reaction by simple filtration, avoiding tedious processes of distillation, chromatographic separation, etc. ${ }^{14}$ Past few years have witnessed a growing interest in the use of microwaves in organic synthesis as they make the reactions extremely fast, cleaner than conventional reactions and lead to higher atom economy (less chemical waste). ${ }^{15}$

In continuation of our interest ${ }^{16}$ in the development of economic and rapid protocol, utilizing microwave energy $^{17}$ and ionic liquids, we report herein a simple synthesis of Nitensidine D.

Retrosynthetic analysis of Nitensidine D (scheme 1) revealed that geranyl amine could well act as the starting precursor. 


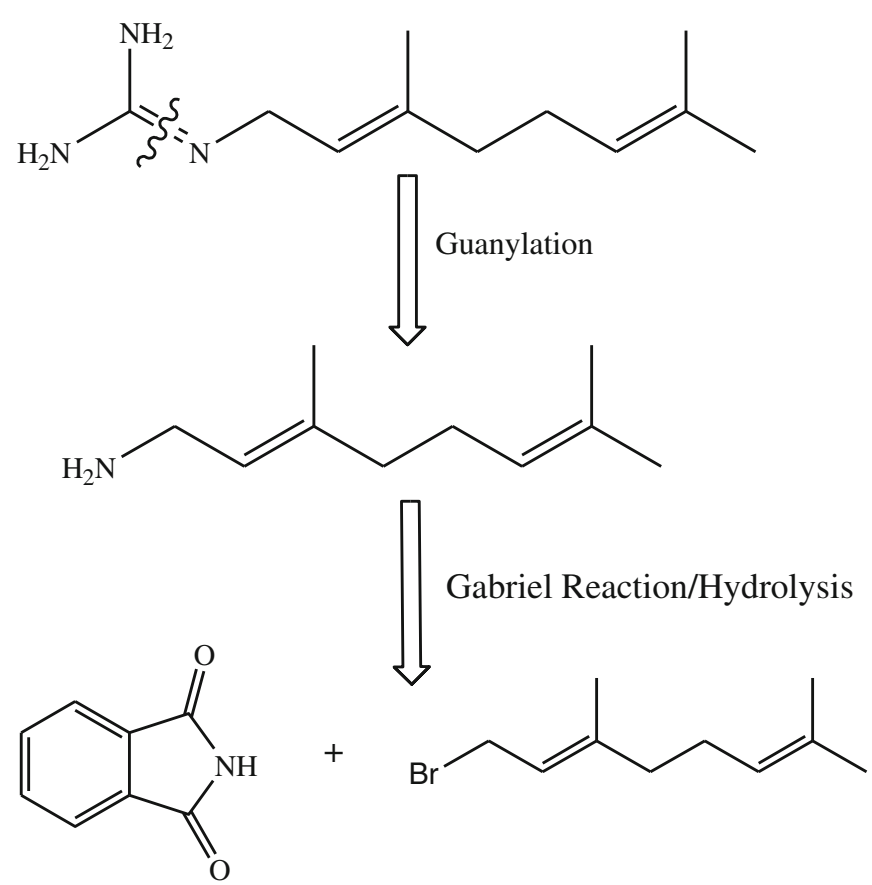

Scheme 1. Retrosynthetic Analysis.

\section{Experimental}

${ }^{1} \mathrm{H}$ NMR (300 MHz) and ${ }^{13} \mathrm{C}$ NMR $(75 \mathrm{MHz})$ spectra were recorded $(\delta / \mathrm{ppm})$ on a Jeol A1 300F spectrophotometer for solutions in $\mathrm{CDCl}_{3}$ with tetramethylsilane (TMS) as internal standard. FT-IR was recorded using Perkin Elmer model 1430 spectrometer. Microwave oven used was focused mono-mode Plazmatronika RM 2001 PC (800W). Melting points were recorded on a Buchi R-535 apparatus.

\subsection{Geranyl bromide (2)}

A solution of geraniol $(1,26 \mathrm{mmol}, 4.0 \mathrm{~g})$ and $\mathrm{CBr}_{4}$ $(30 \mathrm{mmol}, 10.0 \mathrm{~g})$ in $\mathrm{DCM}(11 \mathrm{~mL})$ was prepared in a $100 \mathrm{~mL}$ flask and cooled to $0^{\circ} \mathrm{C}$. $\mathrm{PPh}_{3}(28 \mathrm{mmol}$, $7.3 \mathrm{~g}$ ) was added in portions for over $30 \mathrm{~min}$ with vigorous stirring. Upon addition of triphenyl phosphine, the colourless solution turns pale brown and stirred for an additional $4 \mathrm{~h}$ at room temperature. The mixture was concentrated to brown oil, quickly added to stirring hexane $(22 \mathrm{~mL})$, white ppt. so formed were filtered and remaining solution was concentrated and was purified over a silica gel column (98:2 hexane:EtOAc) to give geranyl bromide (2) in $80 \%$ yield $(4.5 \mathrm{~g})$ as pale yellow oil.

${ }^{1} \mathrm{H} \mathrm{NMR}\left(\mathrm{CDCl}_{3}, 300 \mathrm{MHz}\right): \delta 1.68\left(\mathrm{~s}, 3 \mathrm{H},-\mathrm{CH}_{3}\right)$, $1.74\left(\mathrm{~s}, 3 \mathrm{H},-\mathrm{CH}_{3}\right), 1.75$ (s, 3H, $\left.-\mathrm{CH}_{3}\right), 2.04-2.14(\mathrm{~m}$, $\left.4 \mathrm{H},-\mathrm{CH}_{2}-\mathrm{CH}_{2}-\right), 4.02\left(\mathrm{~d}, 2 \mathrm{H}, \mathrm{J}=8.4 \mathrm{~Hz},-\mathrm{CH}_{2}-\mathrm{Br}\right)$, $5.06\left(\mathrm{t}, 1 \mathrm{H}, J=4.2 \mathrm{~Hz},-\mathrm{CH}=\mathrm{C}(\mathrm{Me})_{2}\right), 5.30(\mathrm{t}$, $\left.1 \mathrm{H}, J=8.4 \mathrm{~Hz},=\mathrm{CH}-\mathrm{CH}_{2}-\mathrm{Br}\right) .{ }^{13} \mathrm{C} \mathrm{NMR}\left(\mathrm{CDCl}_{3}\right.$, $75 \mathrm{MHz}): \delta 15.90,17.71,25.67,26.17,29.66,39.50$, 120.54, 123.53, 131.96, 143.56. IR (neat) $/ v_{\max }\left(\mathrm{cm}^{-1}\right)$ : 838, 985, 1082, 1108, 1376, 1594, 1654, 2855, 2925, 2966.

\section{$2.2 \quad \mathrm{~N}$-geranyl phthalimide (3)}

A mixture of phthalimide $(4.8 \mathrm{mmol}, 0.70 \mathrm{~g})$, geranyl bromide $(2,6.0 \mathrm{mmol}, 1.30 \mathrm{~g})$, immobilized IL $(0.20 \mathrm{~g}, 0.20 \mathrm{mmol}, 3 \mathrm{~mol} \%)$ and potassium carbonate $(18.8 \mathrm{mmol}, 2.6 \mathrm{~g})$ was heated in a commercial microwave oven in an open Erlenmeyer flask at 60$65^{\circ} \mathrm{C}$ for $9 \mathrm{~min}$. having 50:10s heating:cooling cycle each at $80 \%$ power level. After cooling down, the reaction mixture was extracted with methylene chloride (2 $\times 25 \mathrm{~mL}$ ). The combined extract was dried over anhydrous $\mathrm{Na}_{2} \mathrm{SO}_{4}$, filtered and evaporated to get a dark brown residue. It was purified over a silica gel column using hexane:EtOAc $(96: 4)$ as the eluent to give $N$ geranyl phthalimide (3) in $83 \%$ yield $(1.127 \mathrm{~g})$ as white crystalline powder. M.p. $=57-58^{\circ} \mathrm{C}^{18}$

${ }^{1} \mathrm{H} \mathrm{NMR}\left(\mathrm{CDCl}_{3}, 300 \mathrm{MHz}\right): \delta 1.48\left(\mathrm{~s}, 3 \mathrm{H},-\mathrm{CH}_{3}\right)$, $1.54\left(\mathrm{~s}, 3 \mathrm{H},-\mathrm{CH}_{3}\right), 1.74\left(\mathrm{~s}, 3 \mathrm{H},-\mathrm{CH}_{3}\right), 1.91-1.99$ $\left(\mathrm{m}, 4 \mathrm{H},-\mathrm{CH}_{2}-\mathrm{CH}_{2}-\right), 4.19(\mathrm{~d}, 2 \mathrm{H}, J=6.9 \mathrm{~Hz}$, $\left.\mathrm{CH}_{2}-\mathrm{N}-\right), 4.94\left(\mathrm{t}, 1 \mathrm{H}, J=6.9 \mathrm{~Hz},-\mathrm{CH}=\mathrm{C}(\mathrm{Me})_{2}\right)$, $5.18\left(\mathrm{t}, 1 \mathrm{H}, J=6.9 \mathrm{~Hz},=\mathrm{C} H-\mathrm{CH}_{2}-\mathrm{N}-\right), 7.59-7.62$ $(\mathrm{m}, 2 \mathrm{H}, \operatorname{Ar} H), 7.73-7.75(\mathrm{~m}, 2 \mathrm{H}, \operatorname{Ar} H) .{ }^{13} \mathrm{C}$ NMR $\left(\mathrm{CDCl}_{3}, 75 \mathrm{MHz}\right): \delta 16.34,17.63,25.69,26.28,35.73$, 39.46, 118.00, 123.07, 123.82, 131.56, 132.36, 133.67, 140.53, 167.93. IR (neat) $/ v_{\max }\left(\mathrm{cm}^{-1}\right): 946,1085,1171$, 1395, 1653, 1711, 1770, 2929.

\subsection{Geranyl amine (4)}

Hydrazine hydrate $(0.66 \mathrm{~mL}, 21 \mathrm{mmol})$ was added to a stirred solution of $N$-geranyl phthalimide $(3,2.6 \mathrm{mmol}$, $0.736 \mathrm{~g})$ in absolute $\mathrm{EtOH}(10 \mathrm{~mL})$ and the solution was heated to reflux for $8 \mathrm{~h}$. Further, it was cooled to r.t. and the solvent was removed under reduced pressure. Then $20 \% \mathrm{NaOH}$ solution $(10 \mathrm{~mL})$ was added to the residue and extracted with $\mathrm{CH}_{2} \mathrm{Cl}_{2}(3 \times 15 \mathrm{~mL})$. The combined organic extract was dried over anhydrous $\mathrm{Na}_{2} \mathrm{SO}_{4}$, filtered and evaporated to get pure geranyl amine (4) in $93 \%$ yield $(0.37 \mathrm{~g})$ as light yellow oil.

${ }^{1} \mathrm{H}$ NMR $\left(\mathrm{CDCl}_{3}, 300 \mathrm{MHz}\right): \delta 1.53\left(\mathrm{~s}, 3 \mathrm{H},-\mathrm{CH}_{3}\right)$, $1.56\left(\mathrm{~s}, 3 \mathrm{H},-\mathrm{CH}_{3}\right), 1.61$ (s, 3H, $\left.-\mathrm{CH}_{3}\right), 1.92-2.00(\mathrm{~m}$, $\left.4 \mathrm{H},-\mathrm{CH}_{2}-\mathrm{CH}_{2}-\right), 2.14$ (bs, $\left.2 \mathrm{H},-\mathrm{NH}_{2}\right), 3.22$ (d, $2 \mathrm{H}$, $\left.J=6.9 \mathrm{~Hz},-\mathrm{CH}_{2}-\mathrm{NH}_{2}\right), 5.01(\mathrm{t}, 1 \mathrm{H}, J=5.4 \mathrm{~Hz}$, $\left.\mathrm{CH}=\mathrm{C}(\mathrm{Me})_{2}\right), 5.18\left(\mathrm{t}, 1 \mathrm{H}, J=6.9 \mathrm{~Hz},=\mathrm{CH}-\mathrm{CH}_{2}-\right.$ $\left.\mathrm{NH}_{2}\right) .{ }^{13} \mathrm{C} \mathrm{NMR}\left(\mathrm{CDCl}_{3}, 75 \mathrm{MHz}\right): \delta 16.05,17.60$, 
25.60, 26.45, 39.31, 124.06, 124.82, 131.47, 137.08. IR (neat) $/ v_{\max }\left(\mathrm{cm}^{-1}\right): 830,984,1045,1107,1376,1446$, 1587, 1667, 2856, 2916, 2966, 3289, 3363.

\subsection{Formamidinesulfinic acid (6)}

Peracetic acid was prepared by slowly adding acetic anhydride $(50 \mathrm{~mL})$ to $30 \%$ hydrogen peroxide $(45 \mathrm{~g})$ cooled in an ice bath. The addition of two drops of concentrated sulphuric acid caused a violent reaction. After the reaction has subsided, acetic anhydride $(110 \mathrm{~mL})$ was slowly added to the cooled mixture. The mixture was allowed to warm gradually to r.t. and left to stand for at least one day. Methanol $(160 \mathrm{~mL})$ was added and the solution was cooled to $10^{\circ} \mathrm{C}$ in an ice bath. A solution of thiourea $(\mathbf{5}, 10 \mathrm{~g})$ in methanol $(500 \mathrm{~mL})$ was also cooled. The latter was added to the oxidizing mixture in portions at such a rate as to maintain the temperature below $10^{\circ} \mathrm{C}$ (hotter reaction mixtures led to more formamidinesulfonic acid as the product). The solid started forming along with the addition of thiourea and after the complete addition it was filtered and washed with several portions of cold methanol. The product (6) was obtained in $86 \%$ yield $(12.2 \mathrm{~g})$ as white powder. M.p. = $125^{\circ} \mathrm{C}$.

IR (neat) $/ \nu_{\max }\left(\mathrm{cm}^{-1}\right): 597,1054,1186,1462$.

\section{$2.5 \quad$ N-Hexyl guanidine (8)}

To an aqueous solution of $\mathrm{NaOH}(1.0 \mathrm{~mL}, 4.6 \mathrm{mmol}$, $0.184 \mathrm{~g})$ and hexyl amine (7, $2.0 \mathrm{mmol}, 0.202 \mathrm{~g})$, formamidinesulfinic acid $(6,2.30 \mathrm{mmol}, 0.248 \mathrm{~g})$ was added in small portions over $30 \mathrm{~min}$. After approx. $1 / 3$ of formamidinesulfinic acid was added, the reaction mixture became a viscous suspension. The suspension was stirred at r.t. overnight, then heated to $60^{\circ} \mathrm{C}$ and stirred for additional $30 \mathrm{~min}$. The solid product was obtained by cold filtration. White solid was crystallized from $\mathrm{H}_{2} \mathrm{O}$ and the resulting white crystals were washed with small portions of cold $\mathrm{MeOH}$ giving $N$-hexyl guanidine $(\mathbf{8})$ in $85 \%$ yield $(0.24 \mathrm{~g})$. M.p. $=140^{\circ} \mathrm{C}$.

${ }^{1} \mathrm{H} \mathrm{NMR}\left(\mathrm{CDCl}_{3} / \mathrm{DMSO}-d_{6}, 300 \mathrm{MHz}\right): \delta 0.82(\mathrm{t}$, $\left.3 \mathrm{H}, J=6.6,-\mathrm{CH}_{3}\right), 1.22\left(\mathrm{~m}, 6 \mathrm{H},-\left(\mathrm{CH}_{2}\right)_{3}-\mathrm{CH}_{3}\right), 1.45$ $\left(\mathrm{m}, 2 \mathrm{H},-\mathrm{CH}_{2}-\mathrm{CH}_{2}-\mathrm{N}=\mathrm{C}\left(\mathrm{NH}_{2}\right)_{2}\right), 3.02(\mathrm{t}, 1 \mathrm{H}, J=7.2$, $\left.-\mathrm{CH} \mathrm{H}-\mathrm{N}=\mathrm{C}\left(\mathrm{NH}_{2}\right)_{2}\right), 3.24(\mathrm{t}, 1 \mathrm{H}, J=7.2,-\mathrm{CH} H-$ $\left.\mathrm{N}=\mathrm{C}\left(\mathrm{NH}_{2}\right)_{2}\right), 7.2\left(\mathrm{bs}, 1 \mathrm{H},-\mathrm{CH}_{2}-\mathrm{N} H-\mathrm{C}(=\mathrm{NH})-\mathrm{NH}_{2}\right)$, 7.9 (bs, $\left.3 \mathrm{H},-\mathrm{NH}_{2}-\mathrm{C}=\mathrm{NH}\right) .{ }^{13} \mathrm{C} \mathrm{NMR}\left(\mathrm{CDCl}_{3} / \mathrm{DMSO}-\right.$ $\left.d_{6}, 75 \mathrm{MHz}\right): \delta 14.37,22.65,26.48,29.04,31.55,40.21$, 157.21. IR (neat) $/ \nu_{\max }\left(\mathrm{cm}^{-1}\right): 997,1063,1269,1376$, 1463, 1633, 1718, 2852, 2922, 3167, 3333.

\subsection{Nitensidine $D(9)$}

To an aqueous solution of $\mathrm{NaOH}(1.0 \mathrm{~mL}, 4.6 \mathrm{mmol}$, $0.184 \mathrm{~g})$ and geranyl amine $(4,2.0 \mathrm{mmol}, 0.306 \mathrm{~g})$, formamidinesulfinic acid $(\mathbf{6}, 2.30 \mathrm{mmol}, 0.248 \mathrm{~g})$ was added in small portions over $30 \mathrm{~min}$. After approx. 1/3 of formamidinesulfinic acid was added, the reaction mixture became a viscous suspension. The suspension was stirred at r.t. overnight, then heated to $60^{\circ} \mathrm{C}$ and stirred for additional $30 \mathrm{~min}$. It resulted into the formation of light brown oil which was extracted from the aqueous solution by $\mathrm{CHCl}_{3}$, washed with brine and dried over anhydrous $\mathrm{Na}_{2} \mathrm{SO}_{4}$. Solvent was evaporated under reduced pressure and the viscous liquid thus obtained was purified over a column of neutral $\mathrm{Al}_{2} \mathrm{O}_{3}$ using $\mathrm{CHCl}_{3}$ : $\mathrm{MeOH}$ (96:4) as the eluent to give Nitensidine D (9) as colourless oil in $81 \%(0.32 \mathrm{~g})$ yield in the form of a mixture of tautomers in 25.8:74.2 ratio (figure 1).

${ }^{1} \mathrm{H} \mathrm{NMR}\left(\mathrm{CDCl}_{3}, 300 \mathrm{MHz}\right): \delta 1.18$ (bs, $\left.2 \mathrm{H},-\mathrm{NH}_{2}\right)$, $1.52\left(\mathrm{~s}, 3 \mathrm{H},-\mathrm{CH}_{3}\right), 1.59\left(\mathrm{~s}, 6 \mathrm{H}, 2 \times-\mathrm{CH}_{3}\right), 1.93-$ $1.99\left(\mathrm{~m}, 4 \mathrm{H},-\mathrm{CH}_{2}-\mathrm{CH}_{2}-\right), 3.65\left(\mathrm{t}, 2 \mathrm{H}, \mathrm{J}=6.0,-\mathrm{CH}_{2}-\right.$ $\left.\mathrm{N}=\mathrm{C}\left(\mathrm{NH}_{2}\right)_{2}, 74.2 \%\right), 3.99\left(\mathrm{~d}, 2 \mathrm{H}, J=6.6,-\mathrm{CH}_{2}-\mathrm{NH}-\right.$ $\mathrm{C}=\mathrm{NH}(\mathrm{NH} 2), 25.8 \%), 4.16(\mathrm{bs}, 1 \mathrm{H},-\mathrm{NH} \mathrm{H}), 4.46(\mathrm{bs}$, $1 \mathrm{H},-\mathrm{NH} H), 4.96\left(\mathrm{t}, 1 \mathrm{H}, J=7.0,-\mathrm{CH}=\mathrm{C}(\mathrm{Me})_{2}\right)$, $5.11\left(\mathrm{t}, 1 \mathrm{H}, J=6.0,=\mathrm{C} H-\mathrm{CH}_{2}-\mathrm{N}=\mathrm{C}\left(\mathrm{NH}_{2}\right)_{2}\right) .{ }^{13} \mathrm{C}$ NMR $\left(\mathrm{CDCl}_{3}, 75 \mathrm{MHz}\right): \delta 16.36,17.85,25.84,26.58$, $38.85,39.65,121.61,124.12,131.44,138.73,158.18$. IR (neat) $/ \nu_{\max }\left(\mathrm{cm}^{-1}\right): 815,1073,1567,1631,1722 . \mathrm{MS}$ $\mathrm{m} / \mathrm{z}:[\mathrm{M}+1]^{+}$196.2, $[\mathrm{M}+2]^{+}$197.2, 179.2 (calculated for $\mathrm{C}_{11} \mathrm{H}_{21} \mathrm{~N}_{3}$ 195.3079).

\section{Results and Discussion}

To start with the synthesis geranyl bromide was prepared from geraniol using $\mathrm{CBr}_{4} / \mathrm{PPh}_{3}$ in $80 \%$ yield (scheme 2). ${ }^{19}$

Further geranyl bromide was required to be converted to geranyl amine via Gabriel reaction. First step in the Gabriel reaction is the $N$-alkylation of phthalimide to prepare $N$-alkyl phthalimide, which is further hydrolysed to give an amine as the final product. Various routes are available for their synthesis, however, some of these methods are limited by harsh reaction conditions, long reaction times, low yields, use of toxic solvents or catalysts, etc. ${ }^{20}$

To overcome these shortcomings, the $\mathrm{N}$-alkylation of phthalimide has been carried out by using a novel method involving immobilized IL i.e., $\mathrm{SiO}_{2}$-propyltri-butyl chloride $\left(\left[\mathrm{SiO}_{2}-\mathbf{P T B}\right] \mathbf{C l}^{-}\right)$as a heterogeneous phase transfer catalyst under microwave irradiation and solvent free conditions. The reaction conditions were first optimized taking $N$-benzylation of phthalimide with benzyl chloride as the model reaction to get the best 


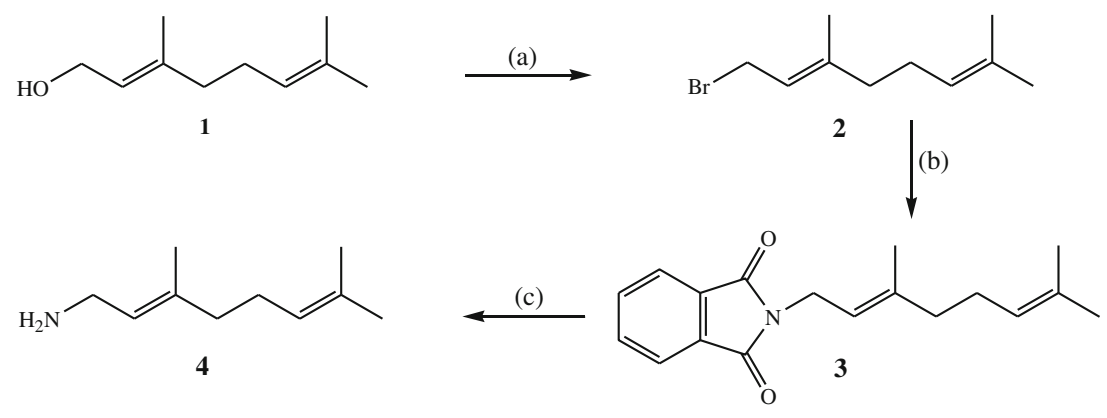

Scheme 2. (a) $\mathrm{CBr}_{4}, \mathrm{PPh}_{3}, \mathrm{DCM}$, 4h, rt, stirr; (b) Phthalimide, $\mathrm{K}_{2} \mathrm{CO}_{3}$, $\mathrm{SiO}_{2}$-IL, MWI, 9 min, $60-65^{\circ} \mathrm{C}$; (c) $\mathrm{NH}_{2} \mathrm{NH}_{2} \cdot \mathrm{H}_{2} \mathrm{O}$, EtOH, 8h, reflux.

minimum reaction time. Not only time, but the power of microwave oven, temperature of operation, as well as quantity of the catalyst were also optimised to give the best conditions as reported.

Then, we proceeded towards geranyl bromide as the reactant which gave the best yield when it was irradiated for $9 \mathrm{~min}$. The reaction resulted into the formation of $N$-geranyl phthalimide as a white solid in $89 \%$ yield. Hydrolysis of the so formed $N$-geranyl phthalimide was done using Ing-Manske procedure involving hydrazine hydrate in absolute EtOH under refluxing conditions i.e., hydrazinolysis ${ }^{21}$ to give geranyl amine as a light yellow oil in $93 \%$ yield.

The next task was the conversion of an amine to a guanidine, where amine nitrogen is incorporated into the newly formed guanidine functional group i.e., guanylation. The common methods for producing guanidino compounds are the reactions of ammonia or amine derivatives with cyanamides, ${ }^{22}$ carbodiimides, ${ }^{23}$ chloroformamidines, ${ }^{24}$ etc. Generally, these materials are toxic, corrosive and/or moisture sensitive. Other popular methods are reactions of amines with substituted $S$-methylisothiourea, ${ }^{25}$ or 2,5-dimethyl-1guanylpyrazole. ${ }^{26}$ The last two methods are generally better than the rest ones, but the reactions usually require a strong basic media and/or heat for some substrates. There are several reports that use $S$-oxides of thiourea i.e., thiourea dioxide/formamidinesulfinic $\operatorname{acid}^{27} \quad\left[\mathrm{HN}=\mathrm{C}\left(\mathrm{NH}_{2}\right) \mathrm{SO}_{2} \mathrm{H}\right]$ and thiourea trioxide/formamidinesulfonic acid ${ }^{28} \quad\left[\mathrm{HN}=\mathrm{C}\left(\mathrm{NH}_{2}\right) \mathrm{SO}_{3} \mathrm{H}\right]$ for the preparation of $\mathrm{N}$-formamidinylamines. Instead of the easy accessibility of formamidinesulfinic acid, only formamidinesulfonic acid and its derivatives were studied in detail. Reason for this neglect could be the earlier reports which claimed that formamidinesulfinic acid gave much poorer yields for guanylation reactions. ${ }^{29}$ Recently, considering this fact that the valuable conversion was at least possible with this cheaper reagent, its $N$-formamidinylation capability with amino acids was explored. ${ }^{30}$ The best yields were obtained (up to 92\%) when the reactions were carried out in the presence of aqueous sodium hydroxide. The awesome results so found in this latest discovery for amino acids, prompted us to screen amines as well for the $N$-formamidinylation reaction using formamidinesulfinic acid. Formamidinesulfinic acid was prepared by oxidizing thiourea with peracetic acid in methanol (scheme 3). ${ }^{28 \mathrm{a}}$
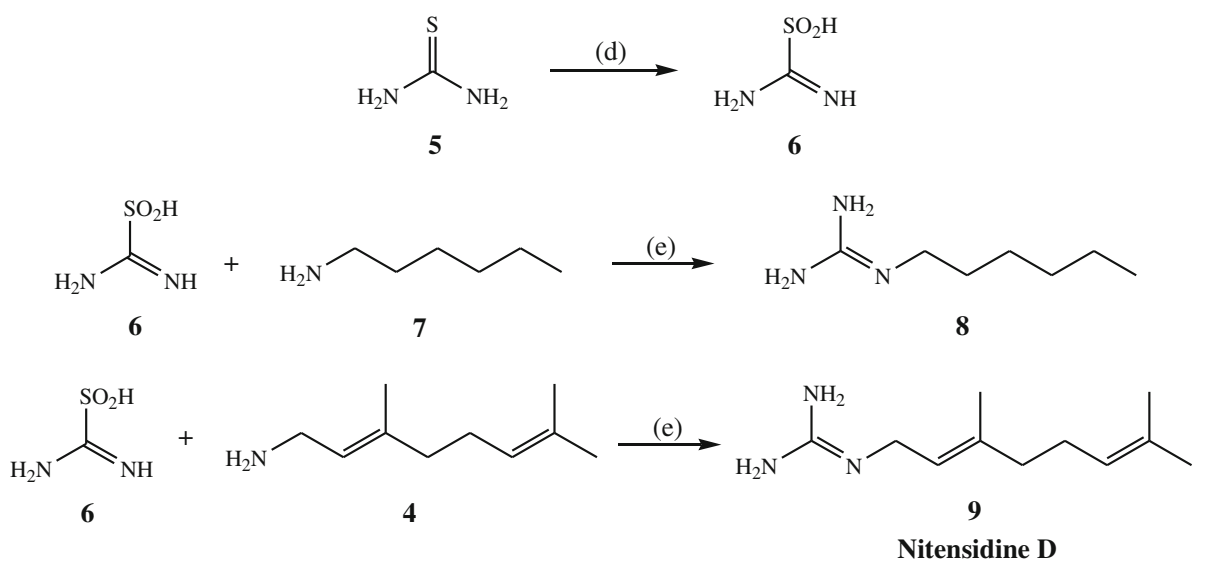

Scheme 3. (d) $\mathrm{CH}_{3} \mathrm{COOOH}, \mathrm{MeOH}$, below $10^{\circ} \mathrm{C}$; (e) aq. $\mathrm{NaOH}$, stirr, $24 \mathrm{~h}$ at rt, $30 \mathrm{~min}$ at $60^{\circ} \mathrm{C}$. 


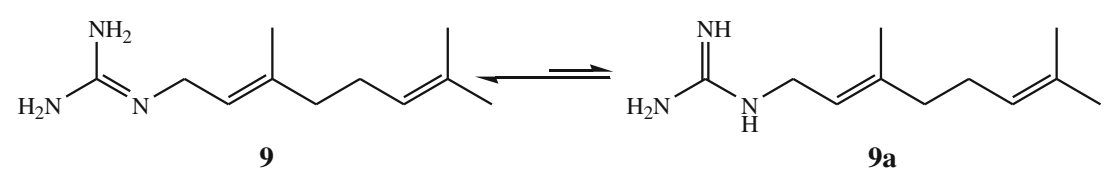

Figure 1. Imine tautomeric forms of guanidine alkaloid Nitensidine D.

In a preliminary experiment, we chose an aliphatic amine i.e., hexyl amine as the substrate and carried out its $N$-formamidinylation using aqueous sodium hydroxide at room temperature. It gave $N$ hexylguanidine as an off white solid in $85 \%$ yield. Then some aromatic amines like aniline, 4-chloroaniline and 4-amino benzoic acid were taken. In this case, either no or very little conversions $(5 \%, 0 \%$ and $10 \%$ respectively) were obtained. Therefore, we believe that this approach would not be practical for aromatic amines, but it is indeed a reliable, inexpensive and efficient method for conversion of aliphatic amines into the corresponding $N$-formamidinyl derivatives. Thus, we proceeded towards the reaction of geranyl amine with formamidinesulfinic acid under the same set of conditions to obtain the title compound i.e., Nitensidine D in $81 \%$ yield (scheme 3 ). Spectral data of the synthesized title compound were compatible with that reported in literature. ${ }^{12}$ Also, its structure was in agreement with a tautomeric form having imine feature which most of the natural guanidines occurring in plants and animals include (figure 1). It is also clear from the proton NMR data that both the tautomers are present in 25.8:74.2 ratio.

\section{Conclusions}

In conclusion, we have achieved an efficient first total synthesis of a naturally occurring guanidine alkaloid, Nitensidine D isolated from ethanol extract of Pterogyne nitens. Geraniol (1) has been used as the starting material. The key steps in the synthesis involved the microwave induced $N$-alkylation of phthalimide using immobilized ionic liquid $\left[\mathrm{SiO}_{2}-\mathrm{PTB}\right] \mathrm{Cl}^{-}$and $N$ formamidinylation of geranyl amine using formamidinesulfinic acid $\left[\mathrm{HN}=\mathrm{C}\left(\mathrm{NH}_{2}\right) \mathrm{SO}_{2} \mathrm{H}\right]$ to afford the title compound (9).

\section{Supporting Information}

Supporting information is available at www.ias.ac.in/ chemsci. ${ }^{1} \mathrm{H}$ NMR, ${ }^{13} \mathrm{C}$ NMR, IR and Mass spectra of the title compound Nitensidine $\mathrm{D}$ are available in the electronic supplementary information.

\section{Acknowledgements}

The authors are thankful to CSIR and UGC-New Delhi (India) for providing financial assistance.

\section{References}

1. Bauer A and Brönstrup M 2014 Nat. Prod. Rep. 3135

2. Zachary D A and Larry E O 2004 Chem. Commun. 40 253

3. Newman D J 2008 J. Med. Chem. 512589

4. Berlinck R G S 2002 Nat. Prod. Rep. 19617

5. Cotton F A, Day V W, Hazen E E and Larsen S 1973 J. Am. Chem. Soc. 954834

6. Schmidtchen F P and Berger M 1997 Chem. Rev. 97 1609

7. Laville R, Thomas O P, Berrué F, Marquez D, Vacelet J and Amade P 2009 J. Nat. Prod. 721589

8. (a) Corral R A, Orazi O and Petruccelli M F 196925 1020; (b) Kamnaing P, Free S N Y F, Fornum Z T, Martin M T and Bodo B 1994 Phytochemistry 361561

9. Crivos M, Martinez M R, Pochettino M L, Remorini C, Sy A and Teves L 2007 J. Ethnobiol. Ethnomed. 32 (1)

10. Bolzani V D S, Gunatilaka A A L and Kingston D G I 1995 J. Nat. Prod. 581683

11. Regasini L O, Fernandes D C, Castro-Gamboa I, Silva D H S, Furlan M, Bolzani V S, Barreiro E J, Bolzani V S, Cardoso-Lopes E M, Young M C M, Torres L B, Vellosa J C R and Oliveira O M M 2008 Quim. Nova. 31802

12. Regasini L O, Castro-Gamboa I, Silva D H S, Furlan M, Barreiro E J, Ferreira PMP, Pessoa C, Lotufo LVC, de Moraes M O, Young M C M and Bolzani V 2009 J. Nat. Prod. 72473

13. (a) Rodgers R and Seddon K 2003 In Ionic Liquids as Green Solvents, Progress and Prospects (Washington DC: American Chemical Society); (b) Wasserscheid $\mathrm{P}$ and Welton T 2007 In Ionic Liquids in Synthesis (Wiley-VCH: Weinheim)

14. Thomson L A and Ellmann J A 1996 Chem. Rev 96555

15. Amarasekara A S and Owereh OS 2010 Catal. Commun. 111072

16. (a) Kad G L, Bhandari M, Kaur J, Rathee R and Singh J 2001 Green Chem. 6 275; (b) Kad G L, Singh V, Kaur K P and Singh J 1997 Tetrahedron Lett. 381079

17. (a) Gupta N, Sonu, Kad G L and Singh J 2007 Catal. Commun. 8 1323; (b) Singh J, Gupta N, Kad G L and Kaur J 2006 Synth. Commun. 36 2893; (c) Shallu, Sharma M L and Singh J 2012 Syn. Commun. 42 1306; (d) Singh A, Sharma M L and Singh J 2008 J. Chem. Res. 148; (e) Singh A, Sharma M L and Singh J 2009 Nat. Prod. Res. $\mathbf{2 3} 1029$ 
18. Harned A M, He H S, Toy P H, Flynn D L and Hanson P R 2005 J. Am. Chem. Soc. 12752

19. Baughman T W, Sworen J C and Wagener K B 2004 Tetrahedron 6010943

20. (a) Onajole O K, Govender P, van Helden P D, Kruger H G, Maguire G E M, Wiid I and Govender 2010 Eur. J. Med. Chem. 45 2075; (b) Wiẹcek M, Kottke T, Ligneau X, Schunack W, Seifert R, Stark H, Handzlik J and Kieć-Kononowicz K 2011 Bioorg. Med. Chem. 19 2850

21. (a) Tanyeli C and Ozeubukeu S 2003 Tetrahedron Asymm. 14 1167; (b) March J 1992 In Advanced Organic Chemistry: Reactions, Mechanisms and Structures ( $4^{\text {th }}$ ed.) (New York: John Wiley \& Sons) p 426

22. Davis TL 1927 Org. Synth. 746
23. Mikolajczyk MM and Kielbasinski P 1981 Tetrahedron 37233

24. Bredereck H and Bredereck K 1961 Chem. Ber. 942278

25. Lal B and Gangopadhyay 1996 Tetrahedron Lett. 37 2483

26. Short J H, Biermacher U, Dunnigan D A and Leth T D 1963 J. Med. Chem. 6275 and references therein

27. Durant G J, Young R C and Tashman Z 1980 U.S. Patent 4210658

28. (a) Miller CE and Bischoff JJ 1986 Synthesis 777; (b) Meryanoff C A, Stanzione R C, Plampin J N and Mills J E 1986 J. Org. Chem. 511882

29. Walter W 1955 Angew. Chem. 67275

30. Jursic BS, Neumann D and McPherson A 2000 Synthesis 121656 